\title{
Simultaneous Estimation of Ondansetron and Pantoprazole in Solid Dosage Form by First Derivative Spectroscopy Method
}

\author{
Smita Mujbaile ${ }^{1}$, Priya Prasad ${ }^{2}$ Sanjay Wate ${ }^{3}$ \\ ${ }^{1,2,3}$ (Pharmaceutical Sciences, Sharad Pawar College of Pharmacy/Nagpur University, India)
}

\begin{abstract}
The objective of this work was to develop and validate simple, rapid, and accurate UV specrophotometric method for simultaneous determination of Ondansetron and Pantoprazole in enteric coated tablet dosage form. UV spectrophotometric method involves first derivative spectroscopy using $288.5 \mathrm{~nm}$ and $310 \mathrm{~nm}$ as zero crossing point for Pantoprazole and Ondansetron respectively. For spectrophotometric method, water was used as a solvent. Both the drug and their mix obeyed Beer-Lamberts law at selected wavelength was observed in concentration range of 0.5-2.5ug/ml of Ondansetron and 5-25ug/ml of Pantoprazole. Results of analysis were analyzed and validated for various parameters according to ICH guidelines. This method was found to be simple, precise, accurate, selective and rapid and can be successfully applied for the determination of pure laboratory mixtures and tablet formulations.
\end{abstract}

Keywords: First derivative spectroscopy, Ondansetron (OND), Pantoprazole (PAN), marketed formulation, and Beer-Lambert Law.

\section{Introduction}

Ondannsetron (OND), 9-Methyl-3-(2-Methyl-1H-imidasol-1-yl)-2, 3-dihydro-1H-carbazol-4(9H)one, antagonizes 5HT-3 receptor both peripherally as well as centrally, block the initiation of the reflux , so is used as antiemetic ,Ondansetron combination with proton pump inhibitors has recently been introduced in the market for the treatment of peptic ulcer, gastroesophagal reflux disease (GERD) and to prevent nausea[1]. Ondansetron is official in USP[2], BP[3], and reported in Martindale[4],and Merk index[5]. Pantoprazole (PAN), 5-(Difluromethoxy)-2-\{[3,4-dimethoxy-2-pyridinyl]Methyl $\}$ sulfinyl $] 1 \mathrm{H}-$ Benzimidazole, is a proton pump inhibitor, which suppress gastric acid secretion by $\mathrm{H}+\mathrm{K}+$-ATPase enzyme system at the secretary surface of the gastric parietal cell[6]. This drug is used for the treatment of duodenal, gastric and esophageal ulceration. Pantoprazole is not an official drug but is reported in Merk index[7], Martindale[8]. Literature survey revealed than several methods are reported for the determination of Ondansetron by UV[9] [10], HPTLC[11], RP-LCUV[12], HPLC[13]. Ion pair RP-HPLC [14] [15], LC[16] in solid dosage form and biological fluids. For Pantoprazole, method reported as HPLC [17] in human plasma, simultaneous estimation by HPLC, HPTLC [18], UV[19] [20]. As no analytical method has so far been indicated for the Ondansetron combination with Pantoprazole, an attempt has been made to estimate them by first order derivative spectrophotometry.

\section{Materials And Method}

\subsection{Materials}

Ondansetron reference standard was obtained as a gift sample from Neon Lab LTD., Mumbai, while Pantoprazole from Zim Lab., Nagpur and Cadila pharma Ltd, Ahmadabad. The drug sample (Tablet), VomizenP manufactured by Wintech Pharma, Mumbai was procured from the market. Label claim for PAN and OND were $40 \mathrm{mg}$ and $4 \mathrm{mg}$ respectively. All other reagents used were of analytical grade for spectrophotometry. Water was used as a mobile phase. Shimanzdu UV/Vis double beam specrophotometric method.

\subsection{Methods}

Accurately weighed amount of standard OND $(25 \mathrm{mg})$ and PAN $(25 \mathrm{mg})$ were transferred to $100 \mathrm{ml}$ volumetric flask separately, dissolved and diluted up to mark with water. The resulting solution was filtered through Whatman filter paper No.41. All solutions were prepared freshly. An aliquot portion of the standard stock solution of OND and PAN were further diluted with water to get the series of concentration of 0.5-2.5 $\mathrm{ug} / \mathrm{ml}$ for OND and $5-25 \mathrm{ug} / \mathrm{ml}$ for PAN. The $10 \mathrm{ug} / \mathrm{ml}$ standard solution of both the drug were scanned in spectrum mode from 400-200nm and the absorption spectra so obtained (Fig 1 and Fig 2 for OND and PAN respectively) were derivetized to obtain first order derivative spectra which are shown in Fig 3 and Fig 4 for OND and PAN respectively and overlain spectra to obtained zero cross point is shown in Fig 5. From first order derivative spectra of PAN and OND in water, zero crossing point $288.5 \mathrm{~nm}$ and $310 \mathrm{~nm}$ for PAN respectively were selected for simultaneous estimation of two drugs. The absorption of above were diluted were recorded in $1^{\text {st }}$ order derivative in quantitation mode at $288.5 \mathrm{~nm}$ for estimation of OND and $310 \mathrm{~nm}$ for PAN. Respective calibration curve were plotted between amplitudes observed at $1^{\text {st }}$ order $(n=1)$, for two drugs at two wavelengths 
against the concentration in the range of $0.5-2.5 \mathrm{ug} / \mathrm{ml}$ and $5-25 \mathrm{ug} / \mathrm{ml}$ for OND and PAN respectively. Estimation of these two drug was done by solving the regression equation i.e. OND, $y=0.001 x-0.0011$ and for PAN $y=-0.0118 x+0.0117$. The concentration of individual drug present in the mixture was determined against calibration curve in quantitation mode. Validity of proposed method was checked by preparing five mixed standard in the ratio1:10 w/w for OND and PAN respectively. Absorbance value were measured at respective selected zero cross point and concentration of two drugs, using respective calibration curve were determined. Validation studies gave satisfactory results. Twenty tablets were accurately weighed and finely powdered. An accurately weighed amount equivalent to $40 \mathrm{mg}$ of PAN (equivalent to $4 \mathrm{mg}$ of OND) was transferred to $100 \mathrm{ml}$ volumetric flask with $50 \mathrm{ml}$ of water. The flask was mechanically shaken for $10 \mathrm{~min}$; finally volume was made to mark with water and filtered. An aliquot of $2.5 \mathrm{ml}$ from stock solution was transferred to different volumetric flasks having $50 \mathrm{ml}$ capacity and volume was made to the mark with the water to give a solution containing $2 \mathrm{ug} / \mathrm{ml}$ of OND and $20 \mathrm{ug} / \mathrm{ml}$ of PAN. This solution was analyzed spectrophotometrically at $288.5 \mathrm{~nm}$ and 310 $\mathrm{nm}$.

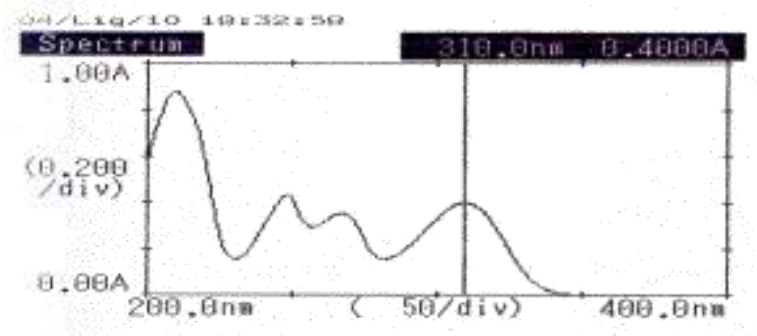

Fig 1. UV spectrum of Ondansetron

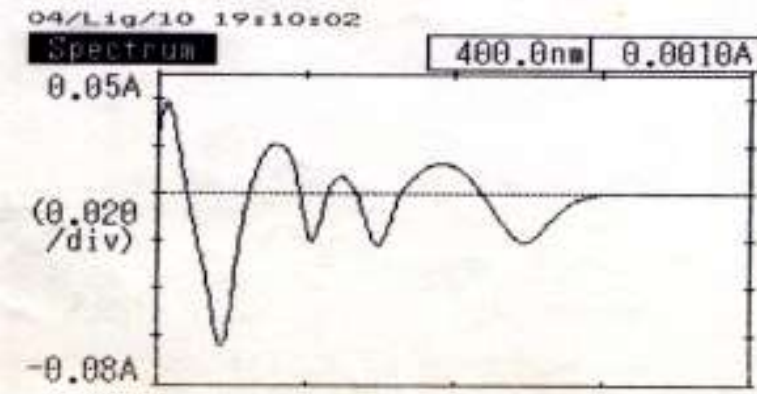

Fig 3. Derivative spectra of Ondansetron

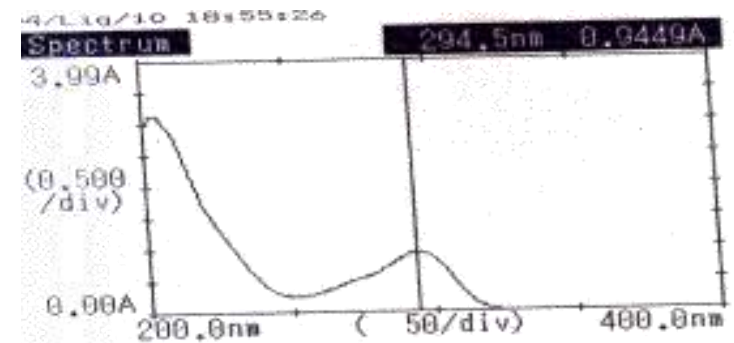

Fig 2. UV spectrum of Pantoprazole

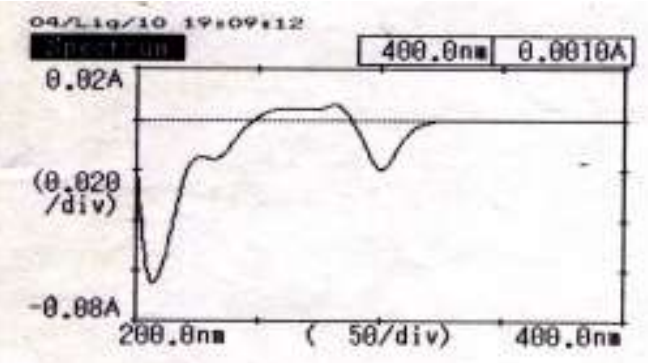

Fig 4. Derivative spectra of Pantoprazole

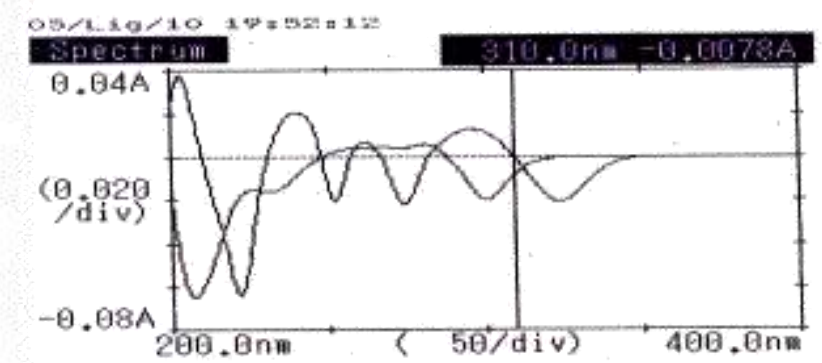

Fig 5. Overlain first order derivative spectrum of PAN and OND

\section{Results And Discussion:}

First derivative absorbance at these wavelengths was substituted in the straight line equation to calculate the amount of the drug present. Result of analysis is reported in Table 1.

Table 1 Assay result of marketed formulation

\begin{tabular}{|c|c|c|c|c|}
\hline Formulation & $\begin{array}{l}\begin{array}{l}\text { Actual } \\
\text { (mg/tab) }\end{array} \\
\text { OND } \\
\end{array}$ & $\begin{array}{l}\text { concentration } \\
\text { PAN }\end{array}$ & \%OND & \%PAN \\
\hline Tablet & 4 & 40 & 100.17 & 1000.42 \\
\hline
\end{tabular}

Accurate, reproducibility and precision of the proposed method were studied with the help of recovery studies that was carried out by addition of standard drug solution to pre analyzed sample at three different levels. The mean of $\%$ recovery was calculated by using formula, $\%$ Recovery $=(\mathrm{T}-\mathrm{A}) / \mathrm{S} \times 100$, where, $\mathrm{T}$ is total amount 
of drug contributed by tablet powder and $\mathrm{S}$ is the amount of pure drug added. The result of recovery studies for OND and PAN was found to be around 99-100\%, indicating that the method are free from interference from excipient and reported in Table 2.The concentrations of two drug where measured three times on the day at intervals of $3 \mathrm{~h}$ and on three different days over a period of one week for intra and inter day study respectively. The limit of detection (LOD)and limit of quantitation(LOQ), where calculated by use of the equation LOD=3.3 /s and $\mathrm{LOQ}=10 / \mathrm{s}$, where is the standard of the blank and $\mathrm{S}$ is the slop of the calibration curve, which are shown in Table 3. The linear regression equation obtained were: absorbance at $288.5 \mathrm{~nm}, \mathrm{y}=0.001 \mathrm{x}-0.0011$ (for OND $\left.\mathrm{r}^{2}=0.9994\right)$ and $310 \mathrm{~nm}, \mathrm{y}=-0.0118 \mathrm{x}+0.0117$ (For PAN $\mathrm{r}^{2}=1$ ). Assay values of OND and PAN were found to be 100.17 and 100.42 respectively with standard deviation of $<1.0$ (Table 1). In first derivative UV spectroscopy, proper selection of zero crossing point completely eliminates the interference of unwanted component and thus concentration of two component can be easily calculated without prior separation of components from combined dosage form.

Table 2 Analysis data and recovery studies

\begin{tabular}{|l|l|lc|}
\hline \multicolumn{1}{|c|}{ Sample Code } & Statiatical Data & \multicolumn{2}{l|}{ OND able Claim } \\
\hline $\begin{array}{l}\text { Laboratory Mixture } \\
(\% \text { Estimation) }\end{array}$ & Mean & 99.77 & 100.19 \\
\hline & SD & 0.7092 & 0.5349 \\
\hline $\begin{array}{l}\text { Yomizen- P Tablet } \\
(\% \text { Label Claim) }\end{array}$ & MSD & 0.0071 & 0.0053 \\
\hline & SD & 100.17 & 100.42 \\
\hline & RSD & 0.2106 & 0.2730 \\
\hline $\begin{array}{l}\text { Recovery Study } \\
\text { Recovery) }\end{array}$ & Mean & 0.0021 & 0.0027 \\
\hline & SD & 100.13 & 99.96 \\
\hline & RSD & 0.2027 & 0.0918 \\
\hline & LOQ & 0.0020 & 0.0009 \\
\hline & LOD & 2.03 & 0.30 \\
\hline
\end{tabular}

Table 3 Result of ruggedness studies

\begin{tabular}{|c|c|c|c|}
\hline Parameter & Statistical Data & OND & PAN \\
\hline \multirow[t]{7}{*}{ Intraday } & Mean & 100.40 & 99.93 \\
\hline & $\mathrm{SD}$ & 0.5656 & 0.0989 \\
\hline & RSD & 0.0056 & 0.0009 \\
\hline & $\mathrm{CV}$ & 0.5634 & 0.0990 \\
\hline & $\mathrm{SE}$ & 0.3265 & 0.0571 \\
\hline & $\mathrm{LOQ}(\mathrm{hg} / \mathrm{ml})$ & 0.5656 & 0.0083 \\
\hline & $\mathrm{LOD}(\mathrm{ug} / \mathrm{ml})$ & 0.1866 & 0.0027 \\
\hline \multirow[t]{7}{*}{ Interclay } & Mean & 99.97 & 99.93 \\
\hline & $\mathrm{SD}$ & 0.0472 & 0.0989 \\
\hline & RSD & 0.0004 & 0.0009 \\
\hline & $\mathrm{CV}$ & 0.0472 & 0.0990 \\
\hline & $\mathrm{SE}$ & 0.0272 & 0.0571 \\
\hline & $\mathrm{LOQ}(\mathrm{ug} / \mathrm{ml})$ & 0.0472 & 0.0083 \\
\hline & $\mathrm{LOD}(\mathrm{ug} / \mathrm{ml})$ & 0.0155 & 0.0027 \\
\hline \multirow[t]{7}{*}{ Different Analyst } & Mean & 99.96 & 99.86 \\
\hline & $\mathrm{SD}$ & 0.0472 & 0.0989 \\
\hline & RSD & 0.0004 & 0.0009 \\
\hline & $\mathrm{CV}$ & 0.0472 & 0.0991 \\
\hline & $\mathrm{SE}$ & 0.0272 & 0.0571 \\
\hline & $\mathrm{LOQ}(\mathrm{ug} / \mathrm{ml})$ & 0.0472 & 0.0083 \\
\hline & $\mathrm{LOD}(\mathrm{ug} / \mathrm{ml})$ & 0.0155 & 0.0027 \\
\hline
\end{tabular}




\section{Conclusion}

From the result it can be concluded that the proposed first derivative spectrometric method is accurate, simple, rapid and selective for simultaneous estimation of Ondansetron and Pantoprazole in tablet dosage form. Hence it can be conveniently adopted for routine quality analysis of the solid dosage form.

\section{Acknowledgements:}

The author are very thankful to Zim Lab , Nagpur, Cadila Pharma Ltd., Ahmadabad AND Neon Lab., Mumbai for providing gift sample of the drug for research work. Author is also thankful to Dr. K. P. Bhansari, Principal, Sharad pawar college of Pharmacy, Nagpur for making available necessary laboratory facilities.

\section{References}

[1] Remington. The Science and Practice of Pharmacy.21 $1^{\text {st }}$ ed. Vol.II Indian Edition Distributed in India by B.I. Publication Pvt. Ltd., 1311.

[2] The United State Pharmacopoeia XII and National Formulary XXIV ed. Asian Ed. Rockville, MD: US Pharmacopoeial convection, 2007, 2799-2804.

[3] British Pharmacopoeia Vol.2, London: The Stationary Office; 2008, 1597-99.

[4] S.C. Sweetman, and Dale M. The Complete Drug Reference. $34^{\text {th }}$ ed.Pharmaceutical Press, London 2002, 1281:1

[5] S. Bhudhavari. The Merk Research Lab. Division of Merk and Co. Inc. Whitehouse station, NJ, $2001,6848$.

[6] Remington. The Science and Practice of Pharmacy. $21^{\text {st }}$ ed.Vol.II Indian Edition, Distributed in India by B.I. Publication Pvt. Ltd., 1301 .

[7] S. Budhavari. The Merk Index $.14^{\text {th }}$ ed. Merk Research Lab. Division of Merk and Co.Inc. Whitehouse station, NJ, $2001,1301$.

[8] S.C. Sweetman, and Dale M. The Complete Drug Reference. $34^{\text {th }}$ ed.Pharmaceutical Press ,London 2002, 1283

[9] A. Raza, A.S. Ijaz , A. Rehman, and U. Rasheed . Spectrometric determination of Ondansetron Hydrochloride in pharmaceutical Bulk and Dosage Form. Journal of Chinese Chemist. Society, 54(1), 2007, 223-27.

[10] P. Ravikumar, M. Muralikrishna, P. Bhanuprakash, B. Anilkumar, and P. Madhusudhan. Derivative Spectrometric estimation of Ondansetron and Paracetamol. E-Journal of Chemistry, 3(12), 2006, 134-36.

[11] P.B. Raval, M. Puranic, S.J. Wadher, and P.G. Yeole. Validated HPTLC Method for Determination of Ondansetron in Combination with Omeprazole or Rabeprazol;e in Solid Dosage Form. Indian Journal of Pharmaceutical Sciences, 70(3), 2008, $386-390$.

[12] R. Sheshala, Y. Darwins, and N. Khan. Development and Validation of an RP-LC-UV Method for the Determination of Ondansetron: Application to Pharmaceutical Dosage Forms. Journal of Chromatographia, 70(1), 2009, 75-81.

[13] T.G. Venkateshwaran, J.T. Stewart, and D.T. King. HPLC Determination of Ondansetron with Selected Medication in 0.9\% Sodium chloride Injection USP. Journal of Liquid Chromatography and Related Technologies, 19(20), 1996, 3355-67.

[14] Z. Dedania, R. Dedania, V. Karkhanis, G.V. Sagar, M. Baldania, and N.R. Sheth. RP-HPLC Method for Simultaneous Estimation of Omeprazole and Ondansetron in Combined Dosage Forms. Asian Journal of Research in Chemistry, 2009 ; $108-111$.

[15] A. Varvara, C.M. Monciu, C. Arama, and C. Popescu. The Liquid Chromatographic Assay of Ondansetron Hydrochloride and Its Impurities Using a New Stationary Phase. Farmacia, 56 (2), 2008, 442-51.

[16] A. Varvara, C.M. Monciu, C. Arama, and C. Popescu. The Liquid Chromatographic Assay of Ondansetron Hydrochloride and Its Impurities Using a New Stationary Phase. Farmacia, 56 (2), 2008, 154-88.

[17] N. Ramakrishna, K.N. Vishvottam, and M. Koteshwara. HPLC Method for the quantitation of Pantoprazole in human plasma. Journal of Chromatography, 822(1), 2005, 326-29.

[18] B.H. Patel, B.N. Suhagia, M.M. Patel, J.R. Patel. Simultaneous estimation of Pantoprazole and Damperidone in Pure Powder and Pharmaceutical Formulation by HPLC and HPTLC Methods. Journal of AOAC, 90(1), 2007, 142-46.

[19] K. Karljikovic -Rajic, D. Novovic , V. Marinkovic, and D. Agbaba. First order UV Derivative spectrometry in the analysis of Omeprazole and Pantoprazole Sodium Salt and corresponding impurities. Journal of Pharmaceutical and Biomedical Analysis, 32(4), 2003, 1019-27.

[20] I. Sulsi, S. and Altinoz. Determination of Pantoprazole in Tabled Dosage Form by Two Different Spectrophotometric Method. Journal of Pharmaceutical Sciences, 28, 200, 385-92. 